\title{
DUSP10 Gene
}

National Cancer Institute

\section{Source}

National Cancer Institute. DUSP10 Gene. NCI Thesaurus. Code C129055.

This gene plays a role in the negative regulation of MAP kinase activity. 